\title{
ANALISIS SPASIAL KETERTINGGALAN DAERAH DI INDONESIA TAHUN 2018 MENGGUNAKAN GEOGRAPHICALLY WEIGHTED LOGISTIC REGRESSION ${ }^{\star}$
}

\author{
Tata Pacu Maulidina ${ }^{1}$, Siskarossa Ika Oktora ${ }^{2 \ddagger}$ \\ 1Politeknik Statistika STIS, Indonesia, 16.9446@stis.ac.id \\ 2Politeknik Statistika STIS, Indonesia, siskarossa@stis.ac.id \\ ‡corresponding author
}

Indonesian Journal of Statistics and Its Applications (eISSN:2599-0802)

Vol 4 No 3 (2020), 528 - 544

Copyright @ 20xx Tata Pacu Maulidina and Siskarossa Ika Oktora. This is an open-access article distributed under the Creative Commons Attribution License, which permits unrestricted use, distribution, and reproduction in any medium, provided the original work is properly cited.

\begin{abstract}
Development inequality in Indonesia has led the developed and underdeveloped regions. Regional backwardness caused by high inequality must be handled properly to prevent negative impacts on national stability. But in fact, the handling of underdeveloped regions is only effective in Western Indonesia, while in Eastern Indonesia tends to be not optimal. This study aims to explore regional backwardness in Indonesia and examines the factors that influence it. Based on data, underdeveloped regions tend to cluster in eastern Indonesia, and the independent variables have large variations between regions. This indicates dependence and spatial heterogeneity. Therefore, this study applies spatial analysis using the Geographically Weighted Logistic Regression (GWLR) method. GWLR shows better performance in modeling the regional backwardness in Indonesia compared to its global model (binary logistic regression). This study provides a local model for each district/city that can be used by local governments to implement more effective policies based on factors that do have significant effects on regional backwardness.
\end{abstract}

Keywords: geographically weighted logistic regression, regional development, regional backwardness, spatial analysis, underdeveloped region.

\section{Pendahuluan}

Salah satu tantangan utama pembangunan di negara berkembang adalah masalah kesenjangan antarwilayah. Indonesia sebagai salah satu negara berkembang tidak lepas dari isu kesenjangan antarwilayah ini. Berdasarkan Inclusive Development

\footnotetext{
* Received Jul 2020; Accepted Nov 2020; Published online on Nov 2020
} 
Index (IDI) yang dirilis oleh World Economic Forum (WEF) pada tahun 2018 ([WEF], 2018), nilai IDI Indonesia menurun dari 4,29 di tahun 2017 menjadi 3,98 di tahun 2018. Hal ini menandakan pemerataan pembangunan di Indonesia tidak menuju ke arah yang lebih baik. Tidak meratanya pembangunan di Indonesia juga dapat tercermin dari kontribusi wilayah terhadap Produk Domestik Bruto (PDB) Nasional yang masih sangat timpang antarpulau. Pada tahun 2018, tercatat sebesar 80,05 persen kontribusi PDB di Indonesia masih didominasi oleh Jawa dan Sumatera. Dominasi PDRB Kawasan Barat Indonesia (Pulau Jawa, Sumatera, dan Bali) terhadap PDB Nasional ini sudah berlangsung selama 32 tahun (1986-2018) dengan nilai yang selalu di atas 80 persen (Bappenas, 2017; [BPS], 2019)

Di awal era reformasi, Indonesia telah menerapkan kebijakan otonomi daerah yang dianggap cukup strategis dalam menyelesaikan masalah kesenjangan antarwilayah (Kuncoro, 2004). Otonomi daerah memberikan kewenangan kepada pemerintah daerah untuk mengurus dan mengatur daerahnya sendiri termasuk perihal pembangunan daerah. Di beberapa negara seperti Brazil, China, dan negaranegara anggota OECD, pembangunan berbasis kewilayahan seperti otonomi daerah ini dianggap sukses ([AfDP], 2015). Namun, di Indonesia, otonomi daerah malah memperburuk kesenjangan pembangunan. Hal ini tercermin pada grafik pada Gambar 1.

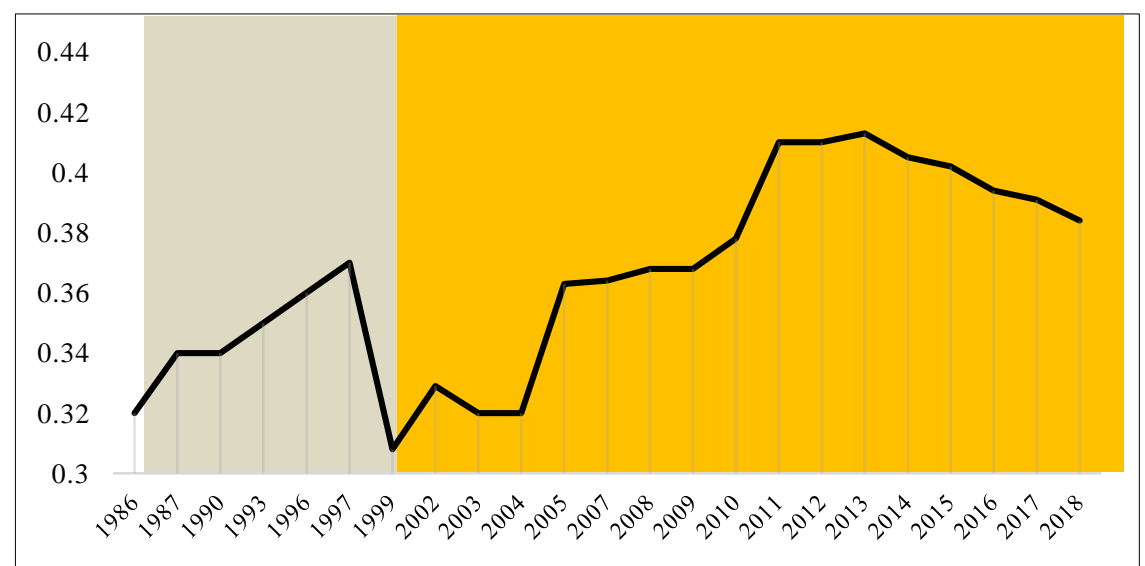

Sumber : Badan Pusat Statistik

Gambar 1: Gini Ratio Indonesia tahun 1986-2018.

Setelah diterapkannya otonomi daerah pada tahun 1999, Gini Ratio di Indonesia memiliki tren yang cenderung naik. Kecenderungan Gini Ratio yang meningkat seperti ini perlu diwaspadai, karena tingginya Gini Ratio menunjukkan bahwa hasil-hasil pembangunan yang dilakukan suatu negara masih belum dapat dinikmati oleh masyarakat secara merata (Syamsuddin, 2011). Hal ini memberikan gambaran bahwa penerapan otonomi daerah masih belum optimal dalam memecahkan masalah pemerataan pembangunan antardaerah di Indonesia. Masalah ketimpangan pembangunan antardaerah di Indonesia ini berimbas pada munculnya daerah tertinggal dan daerah tidak tertinggal.

Daerah tertinggal oleh Bappenas (2017) didefinisikan sebagai kabupaten yang masyarakat serta wilayahnya relatif kurang berkembang dibandingkan daerah lain dalam skala nasional. Selama tiga periode RPJMN, pengentasan daerah tertinggal di Kawasan Barat Indonesia (KBI) terbilang cukup berhasil karena jumlahnya berkurang 
dan proporsinya kecil terhadap jumlah daerah tertinggal secara keseluruhan. Namun di sisi lain, pengentasan daerah tertinggal di Kawasan Timur Indonesia (KTI) nampak tidak terlalu signifikan karena dari periode ke periode jumlahnya masih di atas 100 kabupaten dan mendominasi lebih dari 60 persen jumlah daerah tertinggal di Indonesia. Perbedaan capaian pengentasan daerah tertinggal di wilayah KBI dan KTI menunjukkan bahwa kedua wilayah ini memang membutuhkan penanganan yang berbeda. Hal ini dikarenakan faktor yang menyebabkan daerah tertinggal di masingmasing wilayah dapat berbeda-beda. Kemendes PDTT mengategorikan ketertinggalan suatu daerah di Indonesia berdasarkan 27 indikator yang memengaruhinya yang dikelompokkan kedalam enam kriteria yaitu infrastruktur, aksesbilitas, karakteristik daerah, ekonomi, sumber daya manusia, dan kemampuan keuangan daerah. Selain kriteria tersebut, suatu Daerah Otonom Baru (DOB) yang induknya merupakan daerah tertinggal akan dikategorikan sebagai daerah tertinggal, begitu pula sebaliknya jika induknya tidak tertinggal, maka DOB dinyatakan tidak tertinggal.

Berbagai penelitian terkait ketertinggalan daerah sudah dilakukan, diantaranya adalah penelitian Purwandari dan Hidayat (2017) mengenai variabel-variabel yang berpengaruh terhadap penetapan daerah tertinggal dan daerah tidak tertinggal di Indonesia, variabel yang berpengaruh secara signifikan terhadap pengklasifikasian daerah tertinggal atau tidak tertinggal di Indonesia adalah variabel persentase penduduk miskin dan angka harapan hidup. Penelitian lain yang dilakukan oleh Oktora (2015) menyebutkan bahwa terdapat tiga variabel utama yang berpengaruh terhadap ketertinggalan kabupaten di Indonesia tahun 2014 yaitu konsumsi per kapita, angka harapan hidup, dan persentase rumah tangga pengguna listrik.

Status ketertinggalan daerah juga diduga dapat terjadi karena efek spasial yang terjadi antardaerah, yang mana ketertinggalan di suatu daerah dapat mengakibatkan ketertinggalan daerah lain di sekitarnya, dan sebaliknya, pembangunan yang maju di suatu daerah dapat mendorong daerah di sekitarnya untuk berkembang lebih pesat. Hal ini sejalan dengan hukum pertama tentang geografi oleh Tobler dalam Anselin (1988) yang menyatakan bahwa segala hal memiliki hubungan, tetapi hal yang berdekatan akan lebih berpengaruh dibandingkan hal yang berjauhan. Hubungan ini dinamakan efek spasial. Namun, penelitian ketertinggalan wilayah di Indonesia yang dikaitkan dengan efek spasial masih belum dilakukan.

Berdasarkan latar belakang tersebut, penelitian ini bertujuan untuk mengetahui gambaran umum daerah tertinggal di Indonesia serta mengidentifikasi ada atau tidaknya efek spasial pada status ketertinggalan daerah. Selain itu, penelitian ini juga bertujuan untuk mengetahui variabel-variabel yang signifikan memengaruhi status ketertinggalan daerah di Indonesia.

\section{Metodologi}

\subsection{Bahan dan Data}

Dalam penelitian ini, ketimpangan capaian pembangunan didekati melalui tiga sisi yaitu sisi pembangunan ekonomi dengan indikator kemiskinana dan struktur ekonomi, pembangunan manusia dengan indikator kesehatan dan pendidikan, serta pembangunan infrastruktur dengan indikator keterjangkauan internet dan akses air 
bersih. Ketiga sisi pembangunan ini saling berkaitan satu sama lain. Sumber daya manusia yang berkualitas serta infrastruktur yang memadai akan menunjang pembangunan ekonomi dan secara timbal balik, keberhasilan pembangunan ekonomi akan mempercepat peningkatan kualitas sumber daya manusia dan infrastruktur di suatu wilayah (Damarsari et al., 2015). Ketiga komponen pembangunan ini secara komprehensif dapat dijadikan ukuran keberhasilan pembangunan daerah sekaligus menjadi faktor yang berpengaruh terhadap status ketertinggalan suatu daerah.

Penelitian ini mencakup 514 kabupaten/kota sebagai unit observasi yang terdiri dari 416 kabupaten dan 98 kota. Data yang digunakan merupakan data sekunder yang berasal dari beberapa sumber dengan rincian yang tercantum pada Tabel 1.

Tabel 1. Variabel, Kode Variabel dan Sumber Data

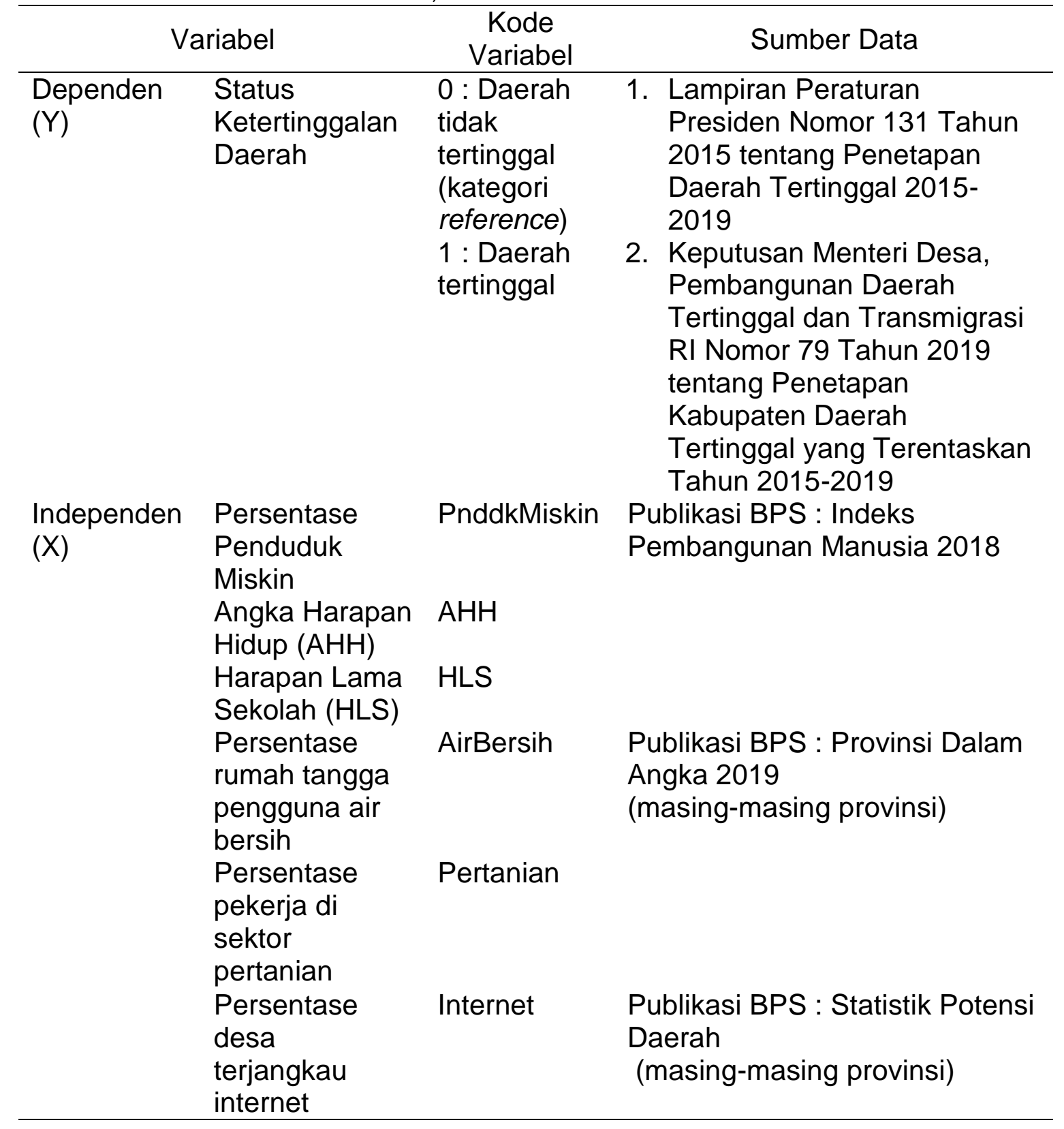




\subsection{Metode Penelitian}

Pengujian setiap hipotesis pada penelitian ini dilakukan dengan taraf signifikansi 10 persen $(\alpha=10 \%)$. Berikut tahapan analisis yang dilakukan dalam penelitian ini:

1. Eksplorasi data secara deskriptif

2. Pengecekkan asumsi non-multikolinieritas

3. Pembentukan model global dengan menggunakan regresi logistik biner sebagai berikut:

$$
g(x)=\operatorname{logit}(\pi(x))=\log \left(\frac{\pi(x)}{1-\pi(x)}\right)=\beta_{0}+\sum_{k=1}^{p} \beta_{k} x_{i k}
$$

dengan $\pi(x)$ merupakan nilai ekspektasi untuk variabel respon dengan nilai antara 0 dan 1 , atau dapat juga disebut sebagai peluang.

4. Pengujian efek spasial berupa dependensi spasial dan heterogenitas spasial pada ketertinggalan daerah. Dependensi spasial diuji menggunakan Moran's I test (Anselin, 1988), sedangkan heterogenitas spasial diuji menggunakan Breusch Pagan (BP) test (Breusch \& Pagan, 1979).

5. Pembentukan matriks pembobot spasial dengan terlebih dahulu menentukan bandwidth optimum untuk masing-masing wilayah dengan menggunakan fungsi adaptive kernel bisquare. Pemilihan bandwidth optimum dilakukan dengan mempertimbangkan nilai AICc (corrected Akaike Infromation Criterion), CV (Cross Validation), SSE (Sum Square of Error) (Fotheringham et al., 2002), dan keberartian model yang dihasilkan (Atkinson et al., 2003).

6. Pembentukan model GWLR yang secara umum dapat dituliskan sebagai berikut :

$$
g\left(x_{i}\right)=\ln \left(\frac{\pi\left(x_{i}\right)}{1-\pi\left(x_{i}\right)}\right)=\beta_{0}\left(u_{i}, v_{i}\right)+\sum_{\boldsymbol{k}=1}^{p} \beta_{k}\left(u_{i}, v_{i}\right) x_{i k}
$$

dimana

$\pi\left(x_{i}\right) \quad$ : peluang kejadian sukses pada wilayah ke- $i$

$\left(u_{i}, v_{i}\right) \quad$ : koordinat (longitude, latitude) letak geografis wilayah amatan ke- $i$

$\beta_{k}\left(u_{i}, v_{i}\right)$ : koefisien regresi untuk variabel penjelas ke- $k$ wilayah amatan ke- $i$

$x_{i k} \quad:$ variabel penjelas ke- $k$ untuk wilayah amatan ke- $i$

Hasil estimasi parameter masing-masing variabel independen pada model GWLR kemudian diuji keragamannya dengan menggunakan Monte Carlo (MC) test (Fotheringham et al., 2002).

7. Pengujian keberartian model GWLR untuk melihat apakah faktor geografis memiliki pengaruh nyata atau tidak terhadap ketertinggalan daerah di Indonesia. Pengujian ini dilakukan dengan membandingkan devians dari model global dan model GWLR. Berikut statistik uji yang digunakan:

$$
F_{h i t}=\frac{D(\widehat{\boldsymbol{\beta}}) / d b_{1}}{D\left(\widehat{\boldsymbol{\beta}}^{*}\right) / d b_{2}}
$$

dengan $D(\widehat{\boldsymbol{\beta}})$ merupakan devians dari model regresi logistik dengan derajat bebas $d b_{1}$ dan $D\left(\widehat{\boldsymbol{\beta}}^{*}\right)$ merupakan devians dari model GWLR dengan derajat bebas $d b_{2}$,

8. Pengujian parameter model GWLR dengan pseudo t-statistic pada masing-masing variabel independen di setiap model lokal (Nakaya et al., 2005)

$$
t_{h i t}\left(u_{i}, v_{i}\right)=\frac{\hat{\beta}_{k}\left(u_{i}, v_{i}\right)}{S E\left(\hat{\beta}_{k}\left(u_{i}, v_{i}\right)\right)} ; k=1,2, \ldots, p
$$


9. Pemilihan model terbaik antara model global dan model GWLR dengan mempertimbangkan nilai CCR, sensitivity, specificity, RMSE, dan Pearson $\chi^{2}$ serta dengan mempertimbangkan uji kelayakan model dan keberartian model yang dihasilkan ((Hosmer \& Lemeshow, 2000; Saefuddin et al., 2012).

\section{Hasil dan Pembahasan}

\subsection{Gambaran Umum Ketertinggalan Dareah dan Faktor-faktor yang Memengaruhinya}

Pada tahun 2018 Indonesia memiliki 60 daerah tertinggal yang ditunjukan dengan warna merah pada Gambar 2. Terlihat bahwa persebaran daerah tertinggal di Indonesia tidak merata. Hanya terdapat 7 daerah tertinggal di Kawasan Barat Indonesia (KBI), 5 di antaranya berada di wilayah kepulauan terluar bagian Barat Indonesia sedangkan 2 lainnya berada di Pulau Sumatera. Jawa dan Kalimantan, yang termasuk kategori pulau besar, tidak memiliki daerah tertinggal sama sekali.

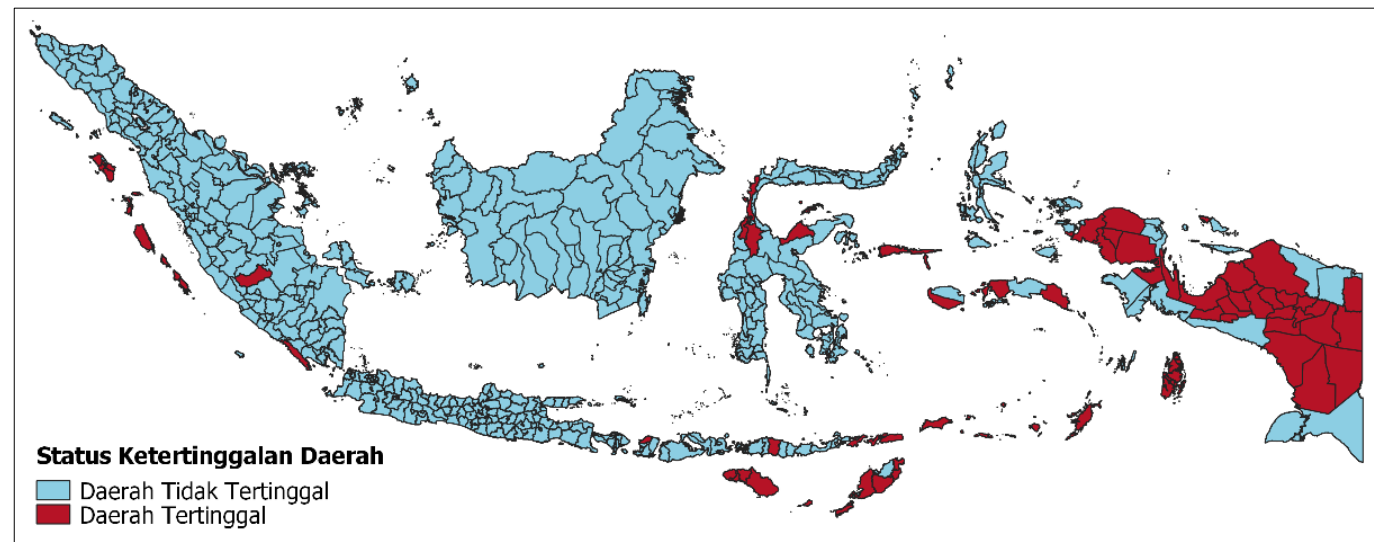

Gambar 2: Peta persebaran daerah tertinggal di Indonesia tahun 2018

Di sisi lain, terdapat 53 daerah tertinggal di Kawasan timur Indonesia (KTI) yang sebagian besar berada di Pulau Papua dan pulau-pulau terluar Indonesia di Gugusan Kepulauan Sunda Kecil. Hal ini menunjukkan adanya pengelompokan daerah tertinggal di $\mathrm{KTI}$ dan daerah tidak tertinggal di KBI yang mengindikasikan bahwa ketertinggalan daerah di Indonesia terjadi karena adanya ketergantungan spasial terhadap wilayah di sekitarnya.

Kolom (6) dan (7) pada Tabel 2 menunjukkan perbandingan karakteristik antara daerah tertinggal dan tidak tertinggal. Daerah tertinggal cenderung memiliki tingkat kemiskinan dan persentase pekerja di sektor pertanian yang lebih tinggi dibandingkan dengan daerah tidak tertinggal. Selain itu, AHH, HLS, penggunaan air bersih, dan ketersediaan jaringan internet di daerah tertinggal memiliki rata-rata yang lebih rendah dibandingkan dengan daerah tidak tertinggal. Secara umum daerah tertinggal memiliki level pembangunan yang lebih rendah dibandingkan dengan daerah tidak tertinggal. Pada Tabel 2 juga terlihat bahwa variabel independen yang berpengaruh terhadap ketertinggalan daerah memiliki variasi yang relatif besar. Hal ini menunjukkan bahwa pembangunan yang diukur dari enam indikator tersebut belum merata di wilayah Indonesia. Selain itu, variasi variabel independen ini mengindikasikan adanya heterogenitas spasial pada variabel-variabel yang memengaruhi ketertinggalan daerah. 
Tabel 2. Statistik deskriptif variabel independen

\begin{tabular}{|c|c|c|c|c|c|c|c|}
\hline \multirow[b]{2}{*}{ Variabel } & \multirow[b]{2}{*}{ Min } & \multirow[b]{2}{*}{ Median } & \multirow[b]{2}{*}{$\operatorname{Max}$} & \multirow[b]{2}{*}{ SD } & \multicolumn{3}{|c|}{ Rata-Rata } \\
\hline & & & & & $\begin{array}{l}\text { Daerah } \\
\text { Tertinggal }\end{array}$ & $\begin{array}{l}\text { Daerah } \\
\text { Tidak } \\
\text { Tertinggal }\end{array}$ & Indonesia \\
\hline (1) & (2) & (3) & (4) & (5) & (6) & (7) & (8) \\
\hline PnddkMiskin* & 1,68 & 10,26 & 43,49 & 7,83 & $27,27 \%$ & $10,41 \%$ & 12,37 \\
\hline Pertanian* & 0 & 39,66 & 100 & 22,26 & $66,06 \%$ & $34,86 \%$ & 38,50 \\
\hline $\mathrm{AHH}^{* *}$ & 54,82 & 69,47 & 77,54 & 3,56 & 64,15 & 69,80 & 69,14 \\
\hline $\mathrm{HLS}^{\star *}$ & 2,95 & 12,71 & 17,26 & 1,42 & 11,20 & 12,94 & 12,74 \\
\hline AirBersih* & 22,22 & 96,88 & 100 & 13,18 & $73,29 \%$ & $93,49 \%$ & 91,13 \\
\hline Internet ${ }^{\star}$ & 0 & 70,59 & 100 & 21,19 & $40,46 \%$ & $71,31 \%$ & 67,71 \\
\hline
\end{tabular}

\subsection{Model Global}

Analisis inferensia dimulai dengan pembentukan model global menggunakan regresi logistik biner. Model global merupakan model yang tidak memasukan faktor geografis ke dalam perhitungan estimasi parameter sehingga hasil estimasi parameternya berlaku untuk seluruh kabupaten/kota.

Sebelum dibentuk model regresi logistik biner, terlebih dahulu dilakukan pengecekkan multikolinieritas pada data. Penelitian ini menggunakan nilai Variance Inflation Factors (VIF) sebagai kriteria untuk mengetahui adanya multikolinieritas pada variabel penjelas. Nilai VIF yang lebih dari 10 menunjukkan adanya multikolinieritas pada variable penjelas (Kutner, 2005).

Tabel 1: Nilai VIF variabel penjelas data ketertinggalan daerah di Indonesia

\begin{tabular}{cc}
\hline Variabel & Nilai VIF \\
\hline PddkMiskin & 1,233 \\
Pertanian & 1,398 \\
AHH & 1,358 \\
HLS & 1,147 \\
Internet & 1,128 \\
AirBersih & 1,275 \\
\hline
\end{tabular}

Tabel 4: Variabel penjelas dan estimasi parameter model regresi logistik biner

\begin{tabular}{ccccc}
\hline Variabel & Estimasi & SE & $\boldsymbol{Z}_{\text {hit }}$ & $\boldsymbol{p}$-value \\
\hline (Intercept) & 49,356 & 12,236 & 4,034 & 0,000 \\
PnddkMiskin & 0,250 & 0,047 & 5,370 & 0,000 \\
pertanian & 0,046 & 0,023 & 1,970 & 0,049 \\
AHH & $-0,622$ & 0,147 & $-4,243$ & 0,000 \\
HLS & $-0,889$ & 0,425 & $-2,090$ & 0,037 \\
internet & $-0,043$ & 0,020 & $-2,141$ & 0,032 \\
AirBersih & $-0,031$ & 0,016 & $-1,906$ & 0,057 \\
\hline
\end{tabular}

Pada Tabel 3 terlihat bahwa VIF untuk setiap variabel penjelas bernilai kurang dari 10. Hal ini menunjukkan bahwa antar variabel penjelas tidak terjadi multikolinieritas 
sehingga semua variabel penjelas dapat digunakan dalam pembentukan model regresi. Hasil estimasi parameter model global ditunjukkan pada Tabel 4. Uji Wald pada masing-masing koefisien menghasilkan $p$-value yang kurang dari 0,1 , hal ini menunjukkan bahwa seluruh variabel independen signifikan berpengaruh terhadap ketertinggalan daerah.

Selain itu, hasil dari uji kebaikan model melalui uji Hosmer-Lemeshow diperoleh $p$ value sebesar 0,992 yang menunjukkan bahwa model logistik biner yang terbentuk merupakan model yang fit. Berikut model global yang terbentuk:

$$
\begin{aligned}
\hat{g}(x) & =49,356+0,250 \text { PnddkMiskin }+ \text { 0,046Pertanian - 0,622AHH - 0,889HLS } \\
& - \text { 0,043/nternet }-0,031 \text { AirBersih }
\end{aligned}
$$

Model global menghasilkan nilai prediksi berupa daerah tertinggal dan tidak tertinggal sehingga dapat dilakukan perbandingan antara hasil prediksi dengan nilai observasi sebenarnya menggunakan tabel klasifikasi. Berdasarkan Tabel 5, secara keseluruhan tingkat akurasi model global dalam mengklasifikasikan ketertinggalan daerah adalah sebesar $96,69 \%$. Terdapat 5 kabupaten/kota yang tidak tertinggal namun diklasifikasikan dalam daerah tertinggal oleh model global. Selain itu, terdapat 12 kabupaten/kota yang tertinggal namun tidak terdeteksi sebagai daerah tertinggal oleh model global. Dengan demikian, terdapat 17 kabupaten/kota yang mengalami missclasiffication (salah klasifikasi).

Tabel 5: Ketepatan klasifikasi model regresi logistik biner

\begin{tabular}{cccc}
\hline \multirow{2}{*}{ Observasi } & \multicolumn{2}{c}{ Prediksi } & Persentase \\
\cline { 2 - 3 } & Tertinggal & Tidak Tertinggal & Ketepatan Klasifikasi \\
\hline Tertinggal & 48 & 12 & $80,00 \%$ (Sensitiv ity) \\
Tidak Tertinggal & 5 & 449 & $98,89 \%$ (Specificity) \\
Correct & Classification Rate $(C C R)$ & $96,69 \%$ \\
\hline
\end{tabular}

\subsection{Pengujian Efek Spasial}

Adanya indikasi ketergantungan spasial dan heterogenitas spasial pada ketertinggalan daerah di Indonesia harus dibuktikan terlebih dahulu. Pada penelitian ini, pemeriksaan dependensi spasial atau autokorelasi spasial dilakukan pada eror yang dihasilkan oleh model global dengan menggunakan uji Moran's I. Nilai Moran's I didapatkan dengan terlebih dahulu mendefinisikan matriks ketetanggaan antarkabupaten/kota sebagai penimbang spasial. Metode yang digunakan untuk membuat penimbang spasial untuk uji Moran's I adalah metode queen contiguity dengan modifikasi. Modifikasi dilakukan terhadap 32 kabupaten yang tidak memiliki tetangga karena merupakan sebuah pulau yang tidak memiliki batas darat dengan kabupaten/kota di sekitarnya. Modifikasi dilakukan dengan cara menginput secara manual kabupaten/kota dengan jarak terdekat dengan masing-masing kabupaten yang tidak memiliki batas darat tersebut. Dengan hal ini, setiap kabupaten/kota dipastikan memiliki minimal 1 tetangga, sehingga dapat dilakukan uji Moran's $I$.

Dengan uji statistik yang dilakukan, nilai Moran'l untuk eror model global bernilai positif yaitu sebesar 0,206 dengan $p$-value 0,000 . Dari hasil ini diketahui bahwa secara 
signifikan terdapat autokorelasi spasial yang positif pada eror model global. Selain menunjukkan terlanggarnya asumsi eror yang seharusnya tidak saling berkorelasi, uji Moran's I yang signifikan positif ini menunjukkan adanya keterkaitan spasial pada data ketertinggalan daerah di Indonesia. Menurut Cliff \& Ord dalam Fotheringham, Brunsdon, \& Charlton (2002), jika residual dari suatu model menunjukkan autokorelasi spasial yang positif, maka standard errors (SE) dari estimasi parameter akan underestimated dan menyebabkan masalah pada model yang dihasilkan.

Menurut Fotheringham (2009), autkorelasi spasial yang positif pada eror model global dapat terjadi akibat adanya heterogenitas spasial. Heterogenitas spasial ini mengindikasikan bahwa variabel penjelas yang berpengaruh terhadap variabel respon berbeda-beda di setiap lokasi. Oleh karena itu, perlu dilakukan pengujian heterogenitas spasial pada model global yang sudah terbentuk. Untuk membuktikan ada atau tidaknya heterogenitas spasial pada ketertinggalan daerah di Indonesia, dilakukan uji Breusch-Pagan (BP) pada eror model global. Statistik uji BP menghasilkan nilai 98,773 , sedangkan nilai chi-square pada tingkat signifikansi $10 \%$ adalah sebesar 10,64 sehingga keputusan yang diambil adalah tolak $\mathrm{H}_{0}$. Secara signifikan, uji ini menunjukkan bahwa model global ketertinggalan daerah di Indonesia memiliki varians eror yang tidak konstan. Dalam konteks spasial, varians eror yang tidak konstan dapat menunjukkan adanya heterogenitas spasial dalam data. Penggunaan parameter yang bersifat global pada data yang mengandung heterogenitas spasial tidak efisien karena akan mengakibatkan estimasi parameter menjadi bias dan kesimpulan yang dihasilkan kurang tepat (Anselin, 1988).

\subsection{Model GWLR}

Geographically Weighted Regression (GWR) merupakan model yang dikembangkan dari model regresi klasik menjadi regresi yang memperhitungkan efek spasial, yang mana estimasi parameter yang dihasilkan tidak lagi berlaku secara global, namun berlaku secara lokal pada masing-masing titik atau lokasi pengamatan (Fotheringham et al., 2002). Model GWR mampu menjelaskan heterogenitas spasial yang ada pada suatu data dengan menghasilkan estimasi parameter yang berbeda-beda di setiap lokasi pengamatan. Selain dapat menjelaskan keadaan nonstasionaritas spasial pada suatu amatan, model GWR juga mampu mengatasi masalah autokorelasi spasial pada residual yang dihasilkan oleh model global. Model GWLR sendiri merupakan perpaduan antara GWR dengan logistic regression (Atkinson et al., 2003).

Sebelum pembentukan model GWLR, perlu adanya matriks pembobot spasial. Dalam penelitian ini, pembentukan matriks pembobot menggunakan fungsi kernel bisquare. Fungsi ini dipilih karena dapat menghasilkan pembobot yang kontinu berdasarkan jarak antara titik centroid amatan ke-i dengan titik centroid amatan di sekitarnya yang masih kurang dari bandwidth. Nilai bandwidth yang digunakan berbeda-beda untuk masing-masing amatan (adaptive bandwidth) karena sebaran amatan yang tidak merata. Pemilihan bandwidth optimum pada penelitian ini dilakukan melalui uji coba yang mempertimbangkan kriteria AICc, CV, Sum of Square Error (SSE) dan kebermaknaan model yang didapat. Uji coba dalam pemilihan bandwidth dilakukan pada nilai bandwidth 20 sampai 514 dengan menggunakan interval 5 . 


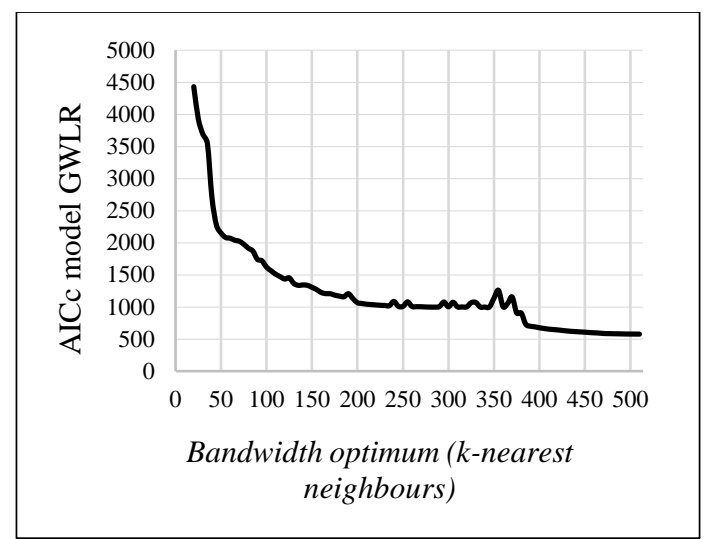

(a)

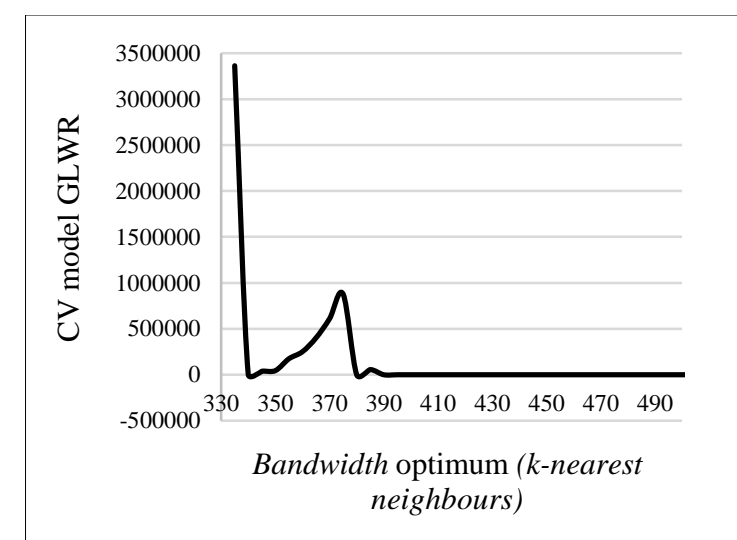

(b)

Gambar 3: (a) Nilai AICc berdasarkan bandwidth (b) Nilai CV berdasarkan bandwidth

Gambar 3(a) menunjukkan nilai AICc model GWLR yang cenderung menurun seiring bertambahnya bandwidth yang digunakan. Nilai AICc terkecil sebesar 575,89 dihasilkan saat nilai bandwidth mencapai nilai maksimal yaitu 514. Model dengan AICc terkecil ini seharusnya menjadi model yang terbaik. Namun, bandwidth yang terlalu besar akan menyebabkan model menjadi bias dan tidak bermakna (Nakaya, et al., 2005). Pada kondisi seperti ini, penulis berupaya memilih bandwidth dengan nilai sekecil mungkin namun tetap menghasilkan model GWLR yang optimal dalam menjelaskan masalah ketertinggalan daerah di Indonesia. Dengan tetap mempertimbangkan nilai AICc, grafik pada Gambar 3(b) menunjukkan penurunan nilai AICc yang relatif stabil di bawah angka 700 saat bandwidth yang digunakan di atas 390. Hal ini dapat menjadi indikasi awal yang menunjukkan bahwa model GWLR terbaik dapat dihasilkan dengan nilai bandwidth di atas angka 390. Selanjutnya, CV yang bernilai kecil dan stabil dihasilkan saat bandwidth yang digunakan di atas 395, yaitu dengan nilai di bawah 2 .

Tabel 6: Nilai AICc, CV, SSE, dan jumlah model lokal tanpa variabel yang signifikan berdasarkan bandwidth yang digunakan

\begin{tabular}{ccccc}
\hline Bandwidth & AICc & CV & SSE & $\begin{array}{c}\text { Jumlah model lokal } \\
\text { (tanpa variabel yang signifikan) }\end{array}$ \\
\hline 395 & 689,95 & 1,98 & 292,5398 & 30 \\
396 & 686,90 & 1,64 & 292,6053 & 22 \\
397 & 682,91 & 1,48 & 292,6917 & 13 \\
398 & 679,85 & 1,31 & 292,7938 & 5 \\
399 & 677,99 & 1,25 & 292,9428 & 2 \\
400 & 675,68 & 1,18 & 293,0485 & 2 \\
401 & 673,89 & 1,14 & 293,0176 & 1 \\
402 & 672,00 & 1,12 & 293,0793 & 0 \\
403 & 670,23 & 1,11 & 293,1170 & 0 \\
\hline
\end{tabular}

Berdasarkan nilai AICc dan CV yang diperoleh, dilakukan uji coba lebih lanjut dengan mempertimbangkan nilai SSE dan keberartian model yang terbentuk. Keberartian model yang terbentuk dilihat melalui banyaknya model lokal yang minimal memiliki 1 variabel penjelas yang signifikan. Berdasarkan Tabel 6, semakin besar 
bandwidth yang digunakan maka semakin meningkat pula nilai SSE yang dihasilkan oleh model GWLR. Namun peningkatan SSE ini relatif kecil sehingga tidak terlalu dipertimbangkan dalam pemilihan model GWLR terbaik. Sebaliknya, penurunan jumlah model lokal tanpa variabel yang signifikan menunjukan hasil yang semakin baik seiring bertambahnya bandwidth. Model GWLR dengan bandwidth 395 masih menghasilkan 30 model lokal tanpa variabel yang signifikan. Saat digunakan bandwidth 402, model GWLR mulai menghasilkan model lokal yang bermakna. Pada bandwidth 402, tidak ada lagi model lokal tanpa variabel yang signifikan atau dengan kata lain setiap kabupaten/kota minimal memiliki 1 variabel yang signifikan. Berdasarkan hal tersebut, bandwidth optimum yang digunakan dalam membentuk model GWLR pada penelitian ini adalah 402. Artinya, terdapat 402 kabupaten/kota tetangga terdekat yang berpengaruh terhadap ketertinggalan suatu kabupaten/kota.

Tabel 7: Ringkasan hasil estimasi parameter model GWLR

\begin{tabular}{lcccccc}
\hline \multirow{2}{*}{ Variabel } & \multicolumn{4}{c}{ Estimasi Parameter Model GWLR } & Monte \\
\cline { 2 - 6 } & Mean & STD & Min & Median & Max & $\begin{array}{c}\text { Carlo Test } \\
(p \text {-value })\end{array}$ \\
\hline Intercept & $-13,406$ & 8,926 & $-28,901$ & $-7,979$ & $-4,761$ & 0,000 \\
PnddkMiskin & 5,426 & 3,841 & 1,308 & 3,553 & 12,188 & 0,000 \\
Pertanian & 2,277 & 2,010 & $-0,171$ & 1,020 & 5,968 & 0,000 \\
AHH & $-4,934$ & 3,204 & $-10,555$ & $-2,888$ & $-1,415$ & 0,000 \\
HLS & $-4,123$ & 4,005 & $-11,696$ & $-1,913$ & $-0,135$ & 0,000 \\
Internet & $-2,021$ & 2,231 & $-6,212$ & $-0,586$ & $-0,077$ & 0,000 \\
AirBersih & $-0,850$ & 0,554 & $-2,214$ & $-0,740$ & 0,056 & 0,002 \\
\hline
\end{tabular}

Ringkasan hasil estimasi parameter model GWLR pada Tabel 7 memperlihatkan secara umum keragman dari koefisien model yang dihasilkan. Misalnya pada variabel penduduk miskin nilai koefisiennya beragam pada masing-masing kabupaten/kota mulai dari 1,308 hingga 12,188. Keragaman estimasi parameter secara statistik dibuktikan dengan Monte Carlo test yang ditampilkan pada kolom (7). P-value yang dihasilkan dari Monte Carlo test pada masing-masing variabel seluruhnya bernilai kurang dari taraf signifikansi $10 \%$ sehingga dapat disimpulkan bahwa koefisien parameter lokal bervariasi antarwilayah.

Tabel 8: Pengujian keberartian model GWLR

\begin{tabular}{cccc}
\hline Model & Devians & $\mathrm{db}$ & Devians/db \\
\hline Regresi Logistik (model global) & 95,811 & 507 & 0,189 \\
GWLR & 641,379 & 499,16 & 1,285 \\
\hline
\end{tabular}

Selanjutnya, dilakukan pengujian kelayakan model GWLR dengan menggunakan uji $\mathrm{F}$ untuk melihat apakah ada pengaruh yang signifikan dari faktor geografis pada model yang terbentuk. Uji dilakukan dengan membandingkan model GWLR terhadap model global. Berdasarkan Tabel 8, dihasilkan $F_{\text {hit }}$ dengan nilai 1,2849 sehingga lebih besar dari nilai $F_{(0,1 ; 507 ; 499,16)}=1,1208$. Keputusan yang diambil adalah menolak $H_{0}$ yang berarti terdapat perbedaan yang signifikan antara model GWLR dan model global. Dengan kata lain, faktor geografis $\left(u_{i}, v_{i}\right)$ pada model GWLR berpengaruh 
secara nyata terhadap ketertinggalan daerah di Indonesia. Hal ini memberikan cukup bukti bahwa model GWLR layak untuk menjelaskan hubungan antara ketertinggalan daerah dengan faktor-faktor yang memengaruhinya.

Pengujian terhadap signifikansi parameter model GWLR dilakukan dengan menggunakan pseudo t-statistic secara parsial untuk melihat signifikansi pengaruh variabel penjelas terhadap variabel respon di setiap kabuapten/kota. Gambar 4 menampilkan peta persebaran variabel yang signifikan dalam model lokal ketertinggalan daerah. Dari gambar tersebut terlihat bahwa setiap kabupaten/kota minimal memiliki 1 variabel penjelas yang signifikan. Perbedaan tingkat signifikansi variabel pada masing-masing wilayah menjadi bukti bahwa ketertinggalan daerah di Indonesia memang dipengaruhi oleh faktor yang berbeda-beda. Oleh karena itu, kebijakan untuk mengentaskan permasalahan ketertinggalan daerah harus memperhatikan karakterisitk masing-masing daerah sehingga kebijakan yang diterapkan akan lebih efektif.

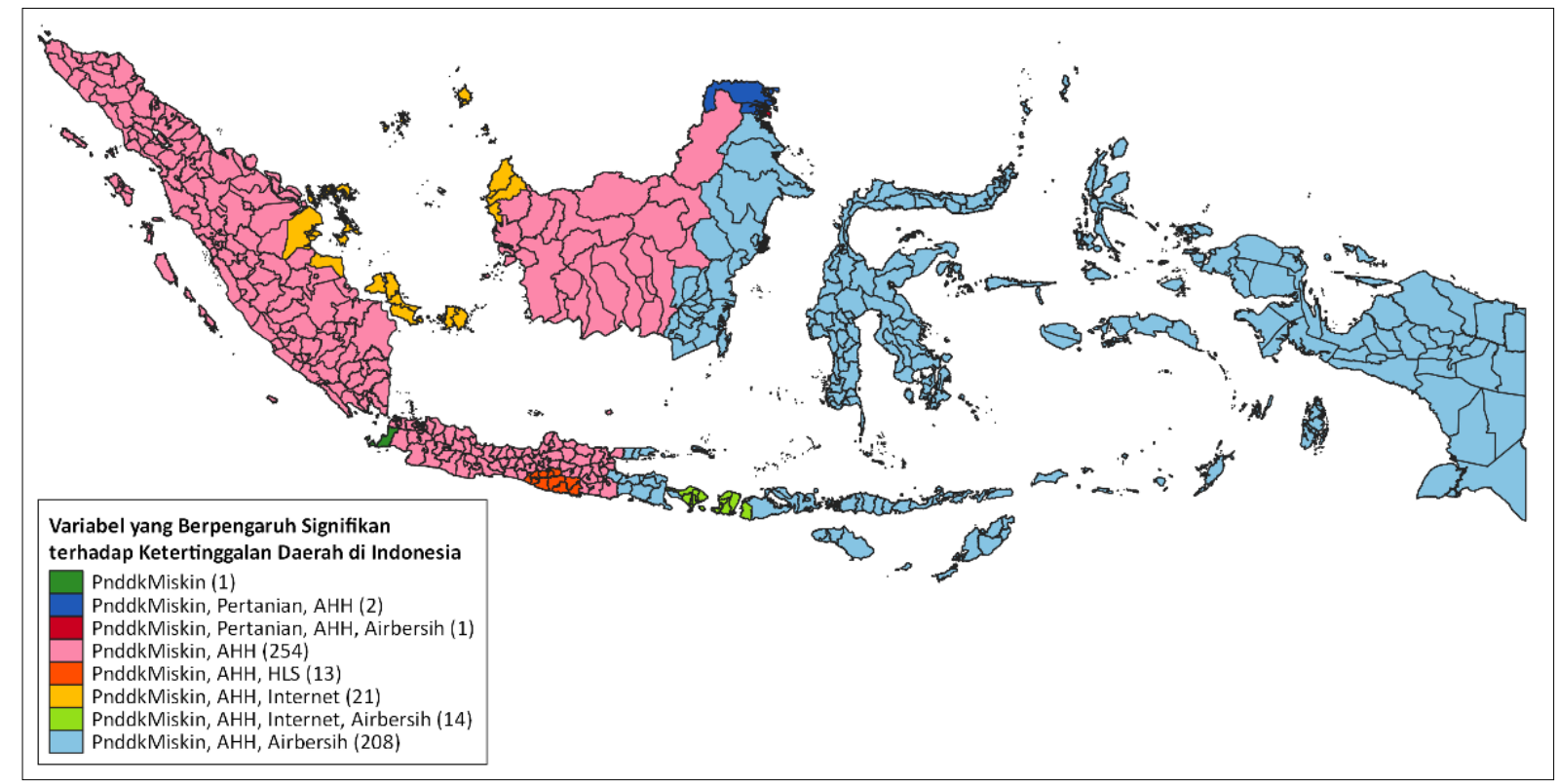

Gambar 4: Peta persebaran variabel yang berpengaruh signifikan terhadap ketertinggalan daerah di Indonesia tahun 2018

Setelah diketahui estimasi parameter dan signifikansi dari masing-masing variabel penjelas, dapat dibentuk model GWLR untuk setiap kabupaten/kota atau disebut dengan model lokal. Berikut contoh model lokal ketertinggalan daerah di Kabupaten Tolikara (kode: 501$)$ :

$$
\begin{gathered}
\hat{g}\left(x_{501}\right)=-4,791+1,327 \text { PnddkMiskin } \\
\left.501{ }^{*}{ }^{*}+0,670 \operatorname{Pertanian}_{501}-2,154 \text { AHH }_{501}{ }^{*}\right) \\
-0,710 \text { HLS }_{501}-0,087 \text { Internet }_{501}-0,842 \text { AirBersih }_{501}{ }^{*)}
\end{gathered}
$$

keterangan: $\left.{ }^{*}\right)=$ signifikan pada tingkat signifikansi $10 \%$

Berdasarkan model tersebut, terdapat tiga variabel yang signifikan berpengaruh terhadap ketertinggalan daerah di Kabupaten Tolikara yaitu persentase penduduk miskin, $\mathrm{AHH}$, dan persentase ruta pengguna air bersih. Hasil perhitungan prediksi probabilitas berdasarkan model lokal tersebut adalah sebesar 0,9995. Dengan 
cutpoint 0,5, maka Kabupaten Tolikara masuk ke dalam kategori daerah tertinggal. Hasil prediksi ini sesuai dengan nilai observasi pada keadaan yang sesungguhnya.

\section{Perbandingan Model GWLR dengan Model Global}

Pada Tabel 9 terlihat bahwa nilai specificity model GWLR tidak mengalami peningkatan dari model globalnya. Walaupun demikian, nilai CCR dan sensitivity mengalami peningkatan. Nilai CCR meningkat sebesar $0,59 \%$ dari $96,69 \%$ pada model global menjadi $97,28 \%$ pada model GWLR. Walaupun peningkatannya terlihat relatif kecil, nilai ini cukup berarti bagi penelitian ini karena terdapat penambahan 3 observasi yang terklasifikasi secara tepat. Penambahan 3 observasi yang terklasifikasi secara tepat ini juga meningkatkan nilai sensitivity model GWLR dari $80 \%$ menjadi 85\%. Hal ini menunjukkan peningkatan dalam ketepatan pen gklasifikasian kabupaten/kota yang berstatus daerah tertinggal melalui model GWLR. Selain peningkatan pada CCR dan sensitivity, kebaikan model GWLR juga ditunjukan dengan nilai RMSE yang jauh lebih kecil dari model global. Dengan nilai RMSE yang lebih kecil, artinya model GWLR lebih konsisten dibandingkan model global dalam prediksi ketertinggalan daerah di Indonesia. Nilai Pearson $\chi^{2}$ pada model GWLR juga jauh lebih kecil dibandingkan model global. Hal ini menunjukkan bahwa model GWLR lebih tepat digunakan untuk memodelkan ketertinggalan daerah di Indonesia.

Tabel 9: Perbandingan model regresi logistik dengan GWLR

\begin{tabular}{cccccc}
\hline Metode & CCR & Sensitivity & Specificity & RMSE & Pearson $\chi^{2}$ \\
\hline Model Global & $96,69 \%$ & $80,00 \%$ & $98,89 \%$ & 51,5644 & 1375,754 \\
(Regresi Logistik) & $97,28 \%$ & $85,00 \%$ & $98,89 \%$ & 0,7544 & 212,197 \\
GWLR & 97,85 &
\end{tabular}

Berdasarkan uji kelayakan model GWLR yang telah dilakukan sebelumnya dan peningkatan performa model GWLR dalam ketepatan pengklasifikasian serta nilai RMSE dan Pearson $\chi^{2}$ yang jauh lebih kecil dibandingkan model global, GWLR merupakan model yang lebih baik dibandingkan model global dalam menjelaskan fenomena ketertinggalan daerah di Indonesia.

\section{Analisis Lanjutan}

Analisis lanjutan di bawah ini dilakukan untuk mengkaji lebih lanjut pengaruh variabelvariabel independen terhadap ketertinggalan daerah. Untuk mempermudah interpretasi, digunakan nilai kecenderungan atau Odds Ratio (OR) yang diperoleh dari exponensial estimasi parameter hasil dari model GWLR.

Nilai OR pada variabel PnddkMiskin seluruhnya bernilai $>1$ dan diketahui signifikan di seluruh kabupaten/kota. Hal ini menunjukkan bahwa peningkatan persentase penduduk miskin akan meningkatkan kecenderungan suatu kabupaten/kota untuk berstatus daerah tertinggal dengan asumsi variabel lainnya konstan. Hasil ini sejalan dengan temuan Purwandari \& Hidayat (2017) yang menunjukkan bahwa daerah dengan tingkat kemiskinan yang lebih tinggi akan 
cenderung diklasifikasikan sebagai daerah tertinggal. Hasil ini juga menunjukkan bahwa, dalam pengentasan daerah tertinggal, tingkat kemiskinan menjadi faktor yang sangat penting untuk diperhatikan mengingat kemiskinan merupakan masalah yang kompleks serta berdampak pada berbagai dimensi kehidupan baik ekonomi, sosial, kesehatan, maupun lingkungan. Sejalan dengan Chen dan Ravallion (2012), kemiskinan sangat erat kaitannya dengan kesejahteraan karena orang yang miskin cenderung memiliki standar hidup yang rendah. Dengan banyaknya orang dengan standar hidup yang rendah di suatu daerah, akan menjadikan daerah tersebut lebih tertinggal dibandingkan dengan daerah lainnya. Hal ini tercermin dari fakta di lapangan bahwa seluruh daerah tertinggal, kecuali Pulau Talabu dan Kepulauan Sula, memiliki tingkat kemiskinan yang lebih besar dari rata-rata nasional.

Nilai OR pada variabel AHH, HLS, dan Internet seluruhnya bernilai $<1$ atau memiliki hubungan yang berbanding terbalik dengan kecenderungan daerah untuk tertinggal. Hal ini sejalan dengan penemuan Purwandari \& Hidayat (2017) yang menyatakan bahwa semakin tinggi angka harapan hidup masyarakat di suatu daerah maka semakin rendah kecenderungan daerah tersebut diklasifikasikan sebagai daerah tertinggal. Dalam rangka pengentasan daerah tertinggal, AHH menjadi salah satu faktor yang penting untuk diperhatikan mengingat $\mathrm{AHH}$ signifikan di seluruh kabupaten/kota, kecuali Kabupaten Pandeglang. Selain itu, dilihat dari rata-rata nilai OR yang dihasilkan, peningkatan 1 tahun harapan hidup di suatu wilayah akan menurunkan kecenderungan untuk tidak tertinggal sebesar 20 kali. Namun peningkatan 1 tahun harapan hidup di suatu wilayah bukan hal yang mudah karena meningkatkan $\mathrm{AHH}$ bukan hanya sekadar meningkatkan derajat kesehatan manusia, tetapi juga peningkatan kesejahteraan manusia itu sendiri (Becker et al., 2005). Terlihat dari data BPS terkait rata-rata peningkatan AHH nasional tiap tahunnya yang hanya berkisar 0,17 tahun atau sekitar 2 bulan. Selain itu, 72 persen kabupaten/kota di Indonesia juga masih memiliki AHH di bawah AHH nasional, dan seluruh daerah tertinggal tergolong dalam kategori ini. Fakta ini menunjukkan bahwa kebijakan terkait peningkatan $\mathrm{AHH}$ merupakan salah satu prioritas dalam upaya pengentasan daerah tertinggal.

Penurunan kecenderungan sebagai daerah tertinggal saat angka HLS mengalami kenaikan juga sejalan dengan pendapat Todaro \& Smith (2015) yang menyatakan bahwa semakin tinggi pendidikan yang ditempuh maka semakin tinggi pula kesejahteraan yang dapat diraih. Namun pengaruh ini hanya signifikan terhadap daerah-daerah di sekitar Yogyakarta. Hal ini menjadi masuk akal karena di Yogyakarta terdapat banyak pusat pendidikan tinggi, bahkan disebut sebagai kota pendidikan, sehingga membuat HLS memiliki pengaruh nyata terhadap status ketertinggalan di wilayah ini dan sekitarnya.

Pengaruh ketersediaan jaringan internet yang menurunkan kecenderungan daerah untuk berstatus sebagai daerah tertinggal sejalan dengan temuan Erdil et al. (2010) yang menyatakan bahwa internet berpengaruh positif terhadap pertumbuhan ekonomi yang digunakan sebagai indikator keberhasilan pembangunan. Namun berdasarkan Gambar 4, keterjangkauan internet tidak berpengaruh signifikan hampir di semua daerah tertinggal. Hasil ini menunjukkan bahwa peningkatan konektivitas 
antardaerah dengan menggunakan jaringan internet belum efektif untuk mengentaskan daerah tertinggal. Penjelasan logis terkait hal ini adalah pada dasarnya pemanfaatan suatu teknologi erat kaitannya dengan pendidikan atau skill seseorang (Todaro \& Smith, 2015). Artinya, jika kualitas manusia dari segi intelektual belum baik, maka pemanfaatan internet tidak akan optimal. Pada kasus daerah tertinggal, peningkatan pembangunan infrastruktur di bidang teknologi dan informasi belum menjadi penting jika tingkat pendidikan di daerah tersebut masih rendah.

Sebagian besar wilayah $(94,75 \%)$ memiliki OR Pertanian yang bernilai $>1$ yang menunjukkan bahwa peningkatan persentase pekerja di sektor pertanian akan meningkatkan kecenderungan suatu daerah untuk berstatus sebagai daerah tertinggal. Hasil ini juga selaras dengan temuan Husna \& Sarpono (2012) bahwa peningkatan persentase rumah tangga pertanian dapat berpengaruh negatif terhadap rata-rata pengeluaran perkapita sehingga memperbesar peluang daerah tersebut dikategorikan sebagai daerah tertinggal. Untuk variabel AirBersih, mayoritas kabupaten/kota memiliki OR yang bernilai $<1$. Hasil ini sejalan dengan penelitian Melliana \& Zain (2013) yang menyatakan bahwa persentase ruta dengan akses air bersih berpengaruh positif terhadap Indeks Pembangunan Manusia (IPM), yang mana IPM merupakan salah satu indikator yang dapat menggambarkan keberhasilan pembangunan di suatu wilayah. Hal ini dikarenakan air bersih merupakan salah satu kebutuhan dasar manusia yang berpengaruh langsung terhadap tumbuh kembang manusia. Sehingga kualitas manusia turut ditentukan oleh jenis air yang ia konsumsi. Fakta yang ada juga menunjukkan bahwa rata-rata rumah tangga pengguna air bersih di daerah tertinggal lebih rendah dari rata-rata nasional.

\section{Simpulan}

Daerah tertinggal di Indonesia cenderung mengelompok di kawasan Timur Indonesia. Daerah tertinggal memiliki tingkat kemiskinan yang tinggi dan masih bergantung pada sektor pertanian sebagai mata pencaharian utama. Selain itu, terdapat bukti bahwa memang terjadi keterkaitan dan heterogenitas spasial pada status ketertinggalan daerah di Indonesia. Dengan diterapkannya GWLR, masing-masing wilayah memiliki model lokal dengan pengaruh dan signfikansi variabel independen yang berbedabeda. Namun secara umum, meningkatnya kemiskinan dan persentase pekerja di sektor pertanian akan meningkatkan kecenderungan suatu wilayah untuk dikategorikan sebagai daerah tertinggal, sedangkan meningkatnya AHH, HLS, penggunaan air bersih, dan keterjangkauan internet akan menurunkan kecenderungan suatu wilayah untuk berstatus sebagai daerah tertinggal.

\section{Daftar Pustaka}

[AfDP] AfDP, OECD, \& UNDP. (2015). The African Economic Outlook 2015: Regional Development and Spatial Inclusion. AfDP, OECD, UNDP.

Anselin, L. (1988). Spatial Econometrics: Methods and Models (Vol. 4). Springer. https://doi.org/10.1007/978-94-015-7799-1 
Atkinson, P. M., German, S. E., Sear, D. A., \& Clark, M. J. (2003). Exploring the Relations Between Riverbank Erosion and Geomorphological Controls Using Geographically Weighted Logistic Regression. Geographical Analysis, 35(1), 58-82. https://doi.org/10.1111/j.1538-4632.2003.tb01101.x

Bappenas. (2017). Prakarsa Pemerintah Daerah dalam Upaya Pengurangan Kesenjangan Wilayah dan Pembangunan Daerah. Jakarta (ID): Bappenas.

Becker, G. S., Philipson, T. J., \& Soares, R. R. (2005). The Quantity and Quality of Life and the Evolution of World Inequality. THE AMERICAN ECONOMIC REVIEW, 95(1), 1-29.

[BPS] Badan Pusat Statistik. (2019). Produk Domestik Regional Bruto ProvinsiProvinsi di Indonesia Menurut Pengeluaran: 2014-2018. Jakarta (ID): Badan Pusat Statistik.

Breusch, T. S., \& Pagan, A. R. (1979). A Simple Test for Heteroscedasticity and Random Coefficient Variation. Econometrica, 47(5), 1287-1294.

Damarsari, R., Juniadi, \& Yulmardi. (2015). Kinerja Pembangunan Daerah Kabupaten/Kota di Provinsi Jambi. Jurnal Prespektif Pembiayaan dan Pembangunan Daerah, 2(3), 161-172.

Fotheringham, A. S., Brunsdon, C., \& Charlton, M. (2002). Geographically Weighted Regression: The Analysis od Spatially Varying Relationships. John Wiley \& Sons.

Hosmer, D. W., \& Lemeshow, S. (2000). Applied Logistic Regression (second edition). John Wiley \& Sons.

Husna, L. N., \& Sarpono, S. (2013). Spatial Small Area Estimation for Determination of Underdeveloped Villages in the Province of YOGYAKARTA (DIY) in 2011. Journal of Indonesian Economy and Business, 28(1), 45-61.

Kuncoro, M. (2004). Otonomi dan Pembangunan Daerah. Jakarta (ID): Erlangga.

Kutner, M. H. (Ed.). (2005). Applied linear statistical models (5th ed). McGraw-Hill Irwin.

Melliana, A. \& Zain, I., 2013. Analisis Statistika Faktor yang Mempengaruhi Indeks Pembangunan Manusia di Kabupaten/Kota Provinsi Jawa Timur dengan Menggunakan Regresi Panel. Jurnal Sains dan Seni, 2(1), 237-242.

Nakaya, T., Fotheringham, A. S., Brunsdon, C., \& Charlton, M. (2005). Geographically weighted Poisson regression for disease association mapping. Statistics in Medicine, 24(17), 2695-2717. https://doi.org/10.1002/sim.2129

Oktora, S. I. (2015). Analisis Multivariate Adaptive Regression Splines (MARS) pada Prediksi Ketertinggalan Kabupaten Tahun 2014. Jurnal Aplikasi Statistika \& Komputasi Statistik, 7(2), 14-14. 
Purwandari, T., \& Hidayat, Y. (2017). Pemodelan Ketertinggalan Daerah di Indonesia Menggunakan Analisis Diskriminan. Pemodelan Ketertinggalan Daerah di Indonesia Menggunakan Analisis Diskriminan, 194-200. Surakarta (ID): Universitas Muhammadiyah Surakarta

Saefuddin, A., Setiabudi, N. A., \& Fitrianto, A. (2012). On comparison between logistic regression and geographically weighted logistic regression: with application to Indonesian poverty data. World Applied Sciences Journal, 19(2), 205-210.

Syamsuddin. (2011). Perhitungan Indeks Gini Ratio dan Analisis Kesenjangan Distribusi Pendapatan Kabupaten Tanjung Jabung Barat Tahun 2006-2010. Jurnal Paradigma Ekonomika, 1(4), 83-102.

Todaro, M. P., \& Smith, S. C. (2015). Economic development (Twelfth edition). Pearson.

[WEF] World Economic Forum. (2018). The Inclusive Development Index 2018 : Summary and Data Highlights. Diunduh dari https://www.weforum.org/reports/theinclusive-development-index-2018. 